\title{
Effect of Kalanchoe crenata Extract on Renal and Liver Impairment, Dyslipedemia and Glycemia in Streptozotocin Induced Diabetic Rats
}

\author{
Emmanuel Effah-Yeboah ${ }^{a^{*}}$, Emmanuel Dartey ${ }^{b}$, Emmanuel Agyapong Asare ${ }^{b}$, \\ Janice Dwomoh Abraham a , James K. Kagya-Agyemang ' ${ }^{\text {, }}$ \\ Gadafi Iddrisu Balali ${ }^{d}$ and Vincent Aboagye ${ }^{\mathrm{e}}$ \\ ${ }^{a}$ Department of Biological Sciences Education, Akenten Appiah-Menka University of Skills Training \\ and Entrepreneurial Development, Ghana. \\ ${ }^{b}$ Department of Chemistry Education, Akenten Appiah-Menka University of Skills Training and \\ Entrepreneurial Development, Ghana. \\ ${ }^{c}$ Department of Animal Science Education, Akenten Appiah-Menka University of Skills Training and \\ Entrepreneurial Development, Ghana. \\ ${ }^{d}$ Department of Theoretical and Applied Biology, Kwame Nkrumah University of Science and \\ Technology, KNUST, Ghana. \\ ${ }^{e}$ Department of Physiology, Korle-bu, University of Ghana.
}

Authors' contributions

All authors contributed enormously in curing out this study. All authors read and approved the final manuscript.

Article Information

DOI: $10.9734 / A R R B / 2021 / v 36 i 1130457$

Editor(s):

(1) Dr. Gonzalo Emiliano Aranda Abreu, Veracruzana University, Mexico.

(1) Mahmood Reza Sadikhani, Lorestan Univeviewers: (2) Belkhodja Hamza, University of Mustapha Stambouli, Algeria. Complete Peer review History, details of the editor(s), Reviewers and additional Reviewers are available here: https://www.sdiarticle5.com/review-history/75641

Original Research Article

Received 11 August 2021

Accepted 22 October 2021

Published 09 December 2021

\begin{abstract}
Introduction: Diabetes mellitus or diabetes is a metabolic ailment which occurs as a result of insulin insufficiency or defect in insulin function, or both that leads to 'hyperglycemia. Diabetes mellitus is a worldwide disease even though its prevalence in other countries vary. Kalanchoe crenata belongs to the family crassulaceae. It is also known locally as miracle plant and often utilized in Africa for medicinal purposes. The study was designed to ascertain the antidiabetic and dyslipidemic activity and effects of the ethanolic extract of both leaves and stem of Kalanchoe crenata on 'streptozotocin incite diabetic rats for three (3) weeks.
\end{abstract}


Methodology: 6-8 weeks old Sprague dawley rats received multiple injection of streptozotocin intraperitoneally $(40 \mathrm{mg} / \mathrm{kg}$ body weight) to induce diabetes melitus. Diabetes mellitus was observed and confirmed after six days of induction. The rats were given ethanolic extract of Kalanchoe crenata remarkably $(10,30$ and $100 \mathrm{mg} / \mathrm{kg}$ ) and $5 \mathrm{mg} / \mathrm{kg}$ glibenclamide orally twice daily for three weeks. Blood glucose, lipids, creatinine, urea, were then determined.

Results: After week three of treatment $5 \mathrm{mg} / \mathrm{kg}$ glibenclamide, 30 and $100 \mathrm{mg} / \mathrm{kg}$ ethanolic extract of Kalanchoe crenata remarkably $(p<0.05)$ decrease glycemia and improved lipidemia by decreasing overall cholesterol, LDL-C and increasing HDL-C likened to the control diabetic group. Also results from treated rats remarkably decrease blood urea nitrogen and creatinine. However, the affirmative control and the sampled treated groups showed curative and regenerative effect in the cells responsible for producing endocrine insulin "beta cells of the islets of Langerhans" located in the pancreas. Kidney and liver tissue sections of treatment groups showed a reversal of diseased insults made by the streptozotocin.

Conclusion: The outcome of the research indicate that given ethanolic extract of Kalanchoe crenata remarkably contains the necessary phytochemicals for the development of a standard and effective herbal medicine for Diabetes mellitus and related complications and also with no toxic effects on the tissues of the liver, pancreas and kidney.

Keywords: Diabetes mellitus; dyslipidemia; Kalanchoe crenata; streptozotocin.

\section{INTRODUCTION}

Diabetes mellitus (DM) is a metabolic ailment which happens as an upshot of insulin insufficiency or defect in insulin function, or both that leads to hyperglycemia [1]. Insulin insufficiency leads to prolonged hyperglycemia with the malfunctioning in fat, protein and carbohydrate metabolism [2]. DM is a worldwide disease even though its prevalence in other countries vary [3]. DM can basically be grouped into type 1 and type 2 diabetes but there are some other types such as gestational diabetes [2]. Type $1 \mathrm{DM}$ results from failure of the islet cells in the pancreas to yield insulin, and presently requires the patient involved to be inoculated with insulin [3]. Type 2 DM on the other hand results from resistance to insulin production, a disorder in which target cells of insulin fail to utilize insulin efficiently, occasionally pooled with complete insulin shortage [1]. Gestational diabetes is a temporary type of DM where the cells located in the pancreas yield inadequate amount of insulin to deal with blood glucose during pregnancy [4].

Increase in ageing populations, intake of food with high calorie, obesity, and sedentary lifestyles has led to the high surge in the number of Diabetic patients globally [5]. India, China, and United State of America are the countries leading in terms of the number of diabetic mellitus patients [6]. Prevalence of type two diabetes worldwide is about 200 million and has been predicted to increase to to 366 million by 2030 [7]. There is little or less information on the occurrence of DM in Ghana. The Crude prevalence rate $(6.3 \%)$ was estimated for Ghanaians of the aged twenty five years upwards from the greater Accra regions of Ghana [8]. All forms of DM have the risk of a long-term health difficulties. These difficulties may appear after so many years about (11 to 20) and might be an early symptom in people who have not be diagnosed in many years [9]. The main long-term problems of DM are the macro and micro blood vessel damage [10]. DM upsurges the menace of cardiovascular diseases [11]. The major macrovascular diseases (atherosclerosis of large arteries) are coronary artery diseases such as angina and myocardial infarction, stroke, and peripheral vascular disease [12]. Most deaths in DM are as a result of complications like coronary artery disease [13].

DM also results in renal disorders that are the cause of many death of diabetic patients [14]. The impaired renal functions results in the development of diabetes nephropathy [15]. There is also a strong correlation between renal dysfunction and oxidative stress in DM which has been reported in several studies [16] resulting in increased morbidity and mortality.

Many of the oral agents such as metformin, repaglinide, glipizide, saxagliptin that are currently used in the management of DM are expensive and many Ghanaians affected with diabetes mellitus cannot afford [17]. Some of these diabetic patients have resorted to the use of medicinal plants believed to contain anti- 
diabetic properties for the management of diabetes mellitus $[18,19]$. Therefore, there is the need to research into the biologically active components of some plants such as Kalanchoe crenata which might have some toxic effects on vital organs such as the liver, kidney and heart. The concentrations and dosages of the plant preparations has be taken into consideration in this research.

Biologically active components such as, alkaloids, glycosides flavonoids, polysaccharides and peptidoglycans are found in some herbs and mushrooms [20]. Flavonoid compounds are large group that occurs in most plants and fungi. The daily intake of flavonoids typically present in herbs and fruits in the diet of humans vary, with approximations of about $23 \mathrm{mg} /$ day to 500 $\mathrm{mg} /$ day and beyond [21]. Flavonoids on the other hand have several physiological activities, which are mainly their ability to inhibit enzyme actions that control glycolysis and gluconeogenesis in the liver and muscle, such that glycolysis becomes favored [22]. Flavonoids also have antioxidant properties which prevent oxidative stress and regulate the immune system response [23].

Kalanchoe crenata (crassulaceae) known as the miracle plant (a vegetable) is used in African countries for the management of inflammatory conditions [24]. The antihyperglycemic, dyslipidimic and toxicity of the extract of both the leaves and stem of kalanchoe crenata was investigated in this research.

The external applications of $K$. crenata are the same as those of Bryophyllum pinnatum [25]. The juice obtained by squeezing the leaves that have been passed over fire slightly is most commonly used for the treatment of headache, general debility, dysentery, smallpox and convulsion. One or two drops of the leaf juice are dropped into the ear for earaches. A poultice of the leaves is applied over wounds and sores. The leaves can be boiled in water and the extract is given as a sedative for asthma and palpitation [25]. Similarly, the leave extract mixed with honey and salt serves as a remedy for chronic cough. Also, dried leaves extract is applied to the infected wound [26].

The treatment of rheumatism, as well as stiff joint in East Africa, is done by slightly heating the leaves and rubbing it over the human body [27]. Solvent type as well as the preparation technique utilized strongly affect the antipathogenic (antimicrobial) potency of plants [28-30]. The aqueous preparation of the plant are being used in parts of west Africa including Ghana to manage diabetes mellitus [27].

\section{MATERIALS AND METHODS}

\subsection{Study Design}

Rats (Sprague Dawley) of both male and female weighing between 114 to $200 \mathrm{~g}$ were chosen at random for the research. Twenty-five (25) rats were obtained from the "Animal House of the University of Cape Coast" (UCC).

\subsection{Study Site}

All animal methods/procedures were carried out at the research facilities of the "Department of Biomedical Sciences (DBS), University of Cape Coast (UCC)". The coordinate for the study site is (coordinate,: 5.1127356, -

1.2828104), Latitude: 5.1043, Longitude: -1.2543 and with the Compound Code: 4P78+3V Cape Coast, Ghana (Fig. 1).

The leaves and stem of Kalanchoe crenata were taken from the "University of Cape Coast (UCC) Science Botanical Garden at Amamoma and were verified and authenticated at the Cape Coast University's herbarium" by Mr. Otoo.

\subsection{Maintenance of Animals}

The rats were kept in the animal house at a temperature around $27 \pm 3^{\circ} \mathrm{C}$ under a $12 \mathrm{hr}$ lightdark cycle. The mice were placed in aluminium cages $(12.5 \times 16.6 \times 7.5$ inches $)$ with soft wood shreds as bedding.

The rats were fed on food and water ad libitum. The test materials were then administered orally using an oral gavage. Rat identification was done using picric acid and fur dye. All animal procedures, techniques and experiments were conducted to comply with the "National Institute of Health Guidelines for Care and Use of Laboratory Animals".

\subsection{Drugs and Chemical}

Triglycerides, Total cholesterol [31], high density lipoprotein cholesterol (HDL-C), low density lipoprotein cholesterol (LDL-C), and very lowdensity lipoprotein cholesterol (VLDL-C) assay kits (Fortress Diagnostic, UK) were used to determine blood biochemistry. 


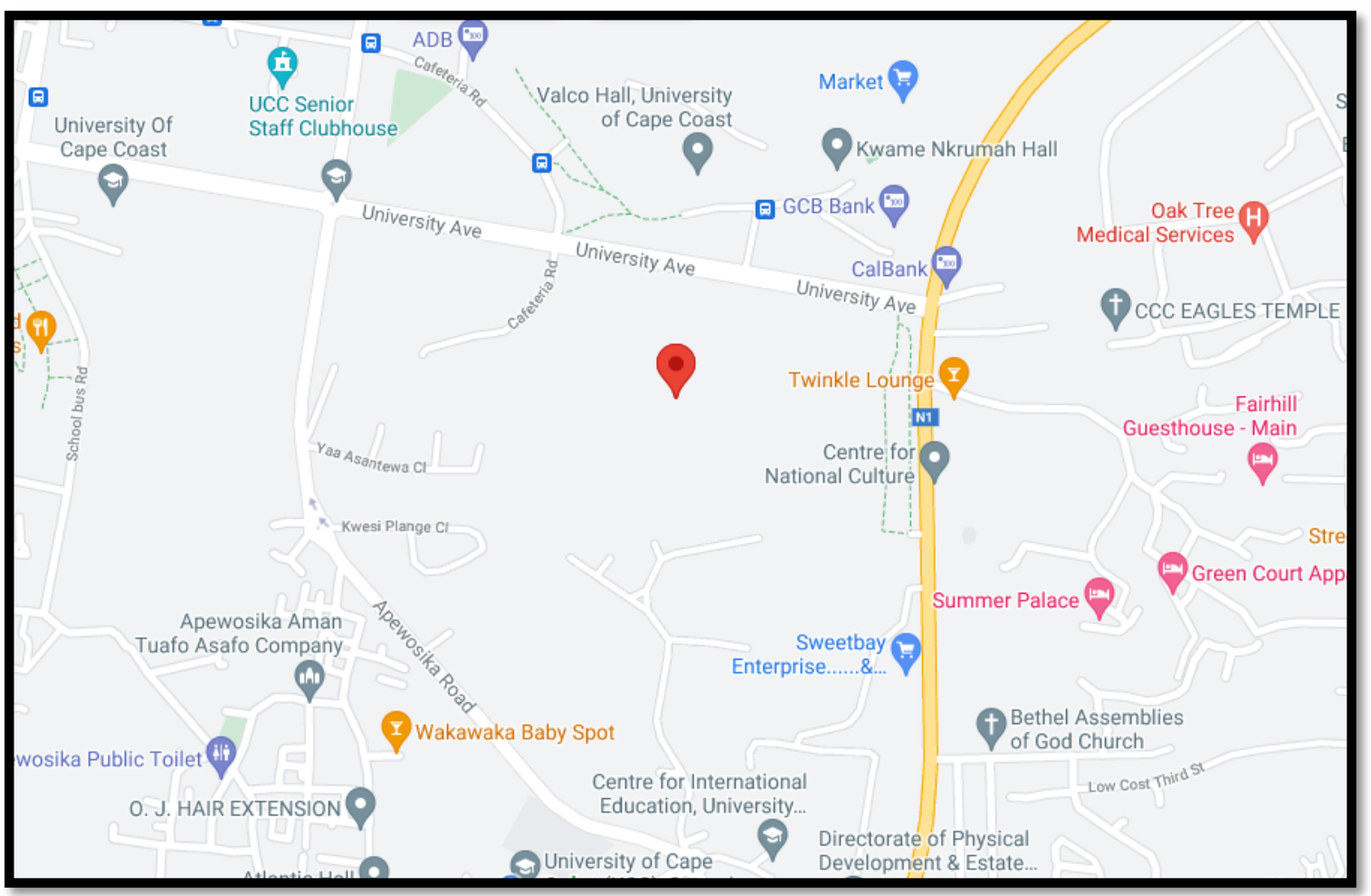

Fig. 1. Map of the study site

All other chemicals such as

glibenclamide

(Arzneimittelwerk Godecke, Freiburg, Germany), normal saline, and streptozotocin "(STZ) (Sigma-Aldrich Inc., St. Louis, MO, USA) were of high purity grade".

\subsection{Preparation of Extract}

1 kilogram Fresh leaves and stem of Kalanchoe. crenata were washed in water and soaked in a mixture of $400 \mathrm{ml}$ of water and $400 \mathrm{ml}$ ethanol. The leaf samples were blended using Sanyo SM (G300) Japan blender. The leaf and stem extracts were then strained using muslin cloth. The ethanolic extract were concentrated under reduced pressure using the rotary evaporator at a temperature of $40^{\circ} \mathrm{C}$. The extract was lyophilized (freeze-dried) to dryness using a freeze drier and the powdered portion of the sample was stored at $4^{\circ} \mathrm{C}$ and used. The extract of the Kalanchoe crenata was then prepared by dissolving 10,30 and $100 \mathrm{mg}$ of freeze- dried extract in $1000 \mathrm{ml}$ of water [32].

\subsection{Phytochemical Screening Test}

The phytochemical constituents of the ethanolic extract was determined using standard phytochemical reagents and procedures.

\subsubsection{Anthraquinones}

Anthraquinones were tested for using Born ranger's test as described by [33]. Processed plant materials were boiled with dilute sulphuric acid. They were then cooled and filtered. The final (filtrate) was then extracted using chloroform and that of dilute ammonia was then added. The layer changing from pink to read is an indication of the presence of nthraquinones derivative.

\subsubsection{Steroids and triterpenoids}

Salkowski test was used to test for the presence of steroids and triterpenoids and according to procedures by [33]. Briefly, extracts were treated in chloroform with few drops of concentrated sulfuric acid, this was then shaken vigorously and left for some time. After few minus, the observation of the appearance of red color at the lower layer shows the presence of steroids while triterpenoids are indicated by yellow colour formation at the lower layer.

\subsubsection{Test for alkaloids}

Three methods were used to test for alkaloids. (i) A portion of the extract was treated with few drops of an aqueous solution of hydrochloric acid and $0.5 \mathrm{ml}$ Mayer's reagent. The formation of a 
white precipitate indicates the presence of alkaloid. (ii) Few drops of $35 \%$ dilute $\mathrm{HCL}$ and $0.5 \mathrm{ml}$ Wagner's reagent was added to a portion of the extract. A brown flocculent precipitate indicates the presence of alkaloid. (iii) A portion of the extract was treated with an equimolar mixture of dilute HCL and Dragendorff's reagent. A brown colouration with precipitate indicates the presence of alkaloid [34].

\subsubsection{Test for cyanogenic glycosides}

About $250 \mu \mathrm{l}$ of the extract was added with an equal volume of cold concentrated sulphuric acid.

Formation of intense green/blue/black/red colour indicates the presence of glycosides [35].

\subsubsection{Test for phenolic compounds}

A portion of the extract was mixed into few drops of diluted Folin Ciocalteu reagent and aqueous sodium carbonate solutions. The mixture was allowed to stand for $10 \mathrm{~min}$ and the formation of grey colour indicates the presence of Phenolic groups [36].

\subsubsection{Test for flavonoids}

Two methods were applied for the qualitative detection of flavonoids. (i) A portion of the extract was dissolved in $10 \% \mathrm{HCl}$ and a few Zinc powder added. The appearance of effervescences with pink colour indicates the presence of flavonoids. (ii) The extract was dissolved in $98 \%$ concentrated $\mathrm{H}_{2} \mathrm{SO}_{4}$, formation of intense colour was observed; this indicates the presence of flavonoids [36].

\subsubsection{Test for terpenoids}

A red to purple colour formation indicates the presence of terpenoids when a chloroform soluble portion of the extract was treated with an equal volume of $98 \%$ concentrated $\mathrm{H}_{2} \mathrm{SO}_{4}$ [35].

\subsubsection{Test for tannins}

A portion of the extract was mixed with few drops of $0.1 \%$ Ferric chloride and observed for brownish green colouration indicating the presence of tannins [35].

\subsubsection{Test for saponins}

About $0.5 \mathrm{ml}$ of the extract was dissolved in $5 \mathrm{ml}$ distilled water in a test tube. The solution was shaken vigorously and observed for a stable persistent froth with a honeycomb structure indicating the presence of saponins [35].

\subsection{Animal Experimentation and Induction of Diabetes Mellitus}

A total of Twenty-five (25) STZ induced diabetic rats at 6-8 weeks of age were used in the experiment to assess the effect of $K$. crenata extract on diabetes. The animals were grouped five (5) per cage and housed under controlled environmental conditions.

Aqueous extract of $K$. crenata was administered by oral gavage. In the diabetic control group normal saline was employed [37].

DM was induced in the mice by the intraperitoneal multiple injection of STZ (10 $\mathrm{mg} / \mathrm{kg}$ ) dissolved in $0.9 \% \mathrm{NaCl}$ daily for six (6) days. Age-matched control rats were also injected with the vehicle alone (thus $0.9 \% \mathrm{NaCl}$ ). After the sixth day of STZ treatment, blood samples were taken from tail veins of the mice using a tail clip and glucose levels measured with a glucometer (one touch). Mice with fasting glucose levels higher than $6.3 \mathrm{mmol} / \mathrm{l}$. were considered as diabetic. [37].

Rats were divided into the following groups:

Group 1 (negative control), STZ induced diabetic rats: normal saline.

Group 2 (positive control), STZ induced diabetic rats: glibenclamide, $10 \mathrm{mg} / \mathrm{kg}$

Group 3 STZ made diabetic rats: extract of kalanchoe crenata, $10 \mathrm{mg} / \mathrm{kg}$

Group 4 STZ made diabetic rats: extract of kalanchoe crenata, $30 \mathrm{mg} / \mathrm{kg}$

Group 5 STZ made diabetic rats: extract of kalanchoe crenata, $100 \mathrm{mg} / \mathrm{kg}$

\subsubsection{Fasting Blood Glucose}

Rats were starved overnight for 10-12 hours. After the fasting, blood was obtained from vein of their tails using a tail clip. Blood glucose levels from each rat were determined using a glucometer (one touch). Some of the blood samples were placed into an EDTA tubes for haematology analysis. Some were centrifuged in vacutainer tubes to obtain the serum for biochemistry analysis.

\subsubsection{Biochemical Analysis}

Serum blood samples were analysed for total cholesterol, Low Density Lipoprotein (LDL), High Density Lipoprotein (HDL), triglycerides, 
creatinine, blood urea nitrogen, alkaline phosphatase (ALP), Alanine Transaminase (ALT), Gamma-glutamyl Transferase (GGT), Aspartate Transaminase (AST) and Total Bilirubin (BIT) using automated biochemistry analyser machine (Genius GS 400, USA).

\subsubsection{Histopathological Studies}

Histopathological investigations were carried out on the pancreas, liver and kidney of both untreated and treated "Sprague dawley" mice as demonstrated by methods by $[38,39]$.

Ten percent of formalin was used in the fixation of the tissues. Using $50-100 \%$ concentrated ethanol, the tissues were then dehydrated. After was, they were rinsed in xylene to eliminate the solvent (ethanol). Lastly, the tissues were embedded in paraffin, this is to ease dissection by strengthening them. Also, the tissues again were "de-paraffinized" using xylene before sectioning. These steps preceded washing them with $100 \%$ to $50 \%$ concentrated ethanol in a decreasing order of concentration before water rehydration was done.

Tissue segments of thickness $6 \mu \mathrm{m}$ were prepared and stained using haematoxylin-eosin $(\mathrm{H}-\mathrm{E})$ dye to increase contrast for photo microscopic observations. The tissues were then visualized using a light microscope with a magnification of $100 x$.

\subsection{Statistical Analysis}

Data were documented in the form of mean \pm SEM. The data were analysed using statistical tools/methods including one-way ANOVA with GraphPad InStat 3.6, followed by Dunnett's multiple comparison test as also used to plot graphs. $P$ values less than 0.05 were considered statistically significant.

\section{RESULTS}

\subsection{Phytochemicals}

Phytochemical investigations of Kalanchoe crenata ethanol extract (EEKC) indicated presence of numerous bioactive components including triterpenes (Tri), anthraquinones
(Ant),steroids (Ste),tannins (Tan),flavonoids (Fla),alkaloids [40], glycosides (Gly), phenolic (Phe), terpenoids (Ter) and saponins [41] (Table 1).

\subsection{Blood Glucose Levels}

\subsubsection{Glucose levels within 3 weeks of treatment after induction}

Normal saline was administered to the control, nothing was given to the normal control glibenclamide to diabetic control and $10 \mathrm{mg} / \mathrm{kg}$, $30 \mathrm{mg} / \mathrm{kg}, 100 \mathrm{mg} / \mathrm{kg}$ kalanchoe crenata extract to the test groups.

Diabetic rats treated with $5 \mathrm{mg} / \mathrm{kg}$ Glibenclamide showed a sharp reduction in glucose level from induction day to week one. There was no decline in glucose level in the second week and there was also a slight decrease in glucose level in the third week. Both 30 and $100 \mathrm{mg} / \mathrm{kg} \mathrm{KC}$ treated diabetic rats also showed a very sharp drop in glucose levels after the third week of treatment compared to the glibanclamide treated diabetic rats. The $10 \mathrm{mg} / \mathrm{kg} \mathrm{KC}$ treated rats also showed a sharp reduction in glucose levels within the first week after treatment. The level reduced further in the third week after treatment but not to the level as compared to the glibenclamide treated rats. After three weeks of treatment there were no significant differences in the change of blood glucose levels between the $5 \mathrm{mg} / \mathrm{kg}$ Glibenclamide control and $10 \mathrm{mg} / \mathrm{kg} \mathrm{KC}, 30$ $\mathrm{mg} / \mathrm{kg} \mathrm{KC}$ and $100 \mathrm{mg} / \mathrm{kg} \mathrm{KC} \mathrm{(}=0.7191$ ) (Fig. 2).

\subsubsection{Changes in glucose level after treatments}

Normal saline was administered to the negative control, nothing was administered to the normal control, glibenclamide to diabetic control and 10 $\mathrm{mg} / \mathrm{kg}, 30 \mathrm{mg} / \mathrm{kg}, 100 \mathrm{mg} / \mathrm{kg}$ kalanchoe crenata extract to the test groups (Fig. 3).

After the third week of treatment, there was a significant difference between the $5 \mathrm{mg} / \mathrm{kg}$ and control $(p<0.05)$ and between $100 \mathrm{mg} / \mathrm{kg} \mathrm{KC}$ $(p<0.05)$ compared with the control. There was a highly significant difference between the 30 $\mathrm{mg} / \mathrm{kg} \mathrm{KC}$ and the control group $(\mathrm{p}<0.0001)$.

Table 1. Results on phytochemical screening

\begin{tabular}{lllllllllll}
\hline $\begin{array}{l}\text { Compound in } \\
\text { plant extract }\end{array}$ & Alk & Gly & Phe & Fla & Tri & Ant & Ste & Sap & Tan & Ter \\
\hline & +++ & +++ & ++ & +++ & +++ & +++ & +++ & +++ & +++ & ++ \\
\hline \multicolumn{18}{c}{+ indicates presence } & & & & &
\end{tabular}




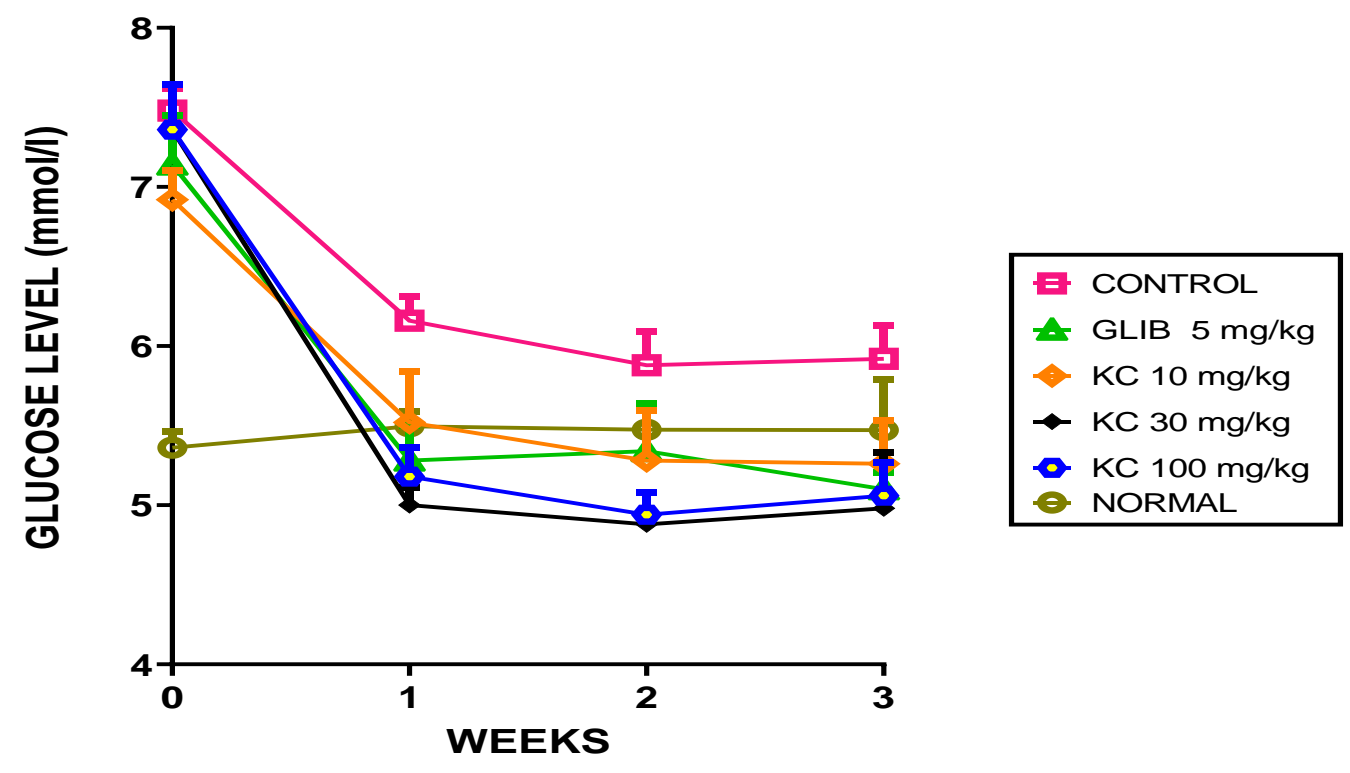

Fig. 2. Changes in glucose levels in $\mathrm{mmol} / \mathrm{l}$ within 3 weeks of treatment after induction Error bars denote $S E M, n=5$, significant difference: $p<0.05$

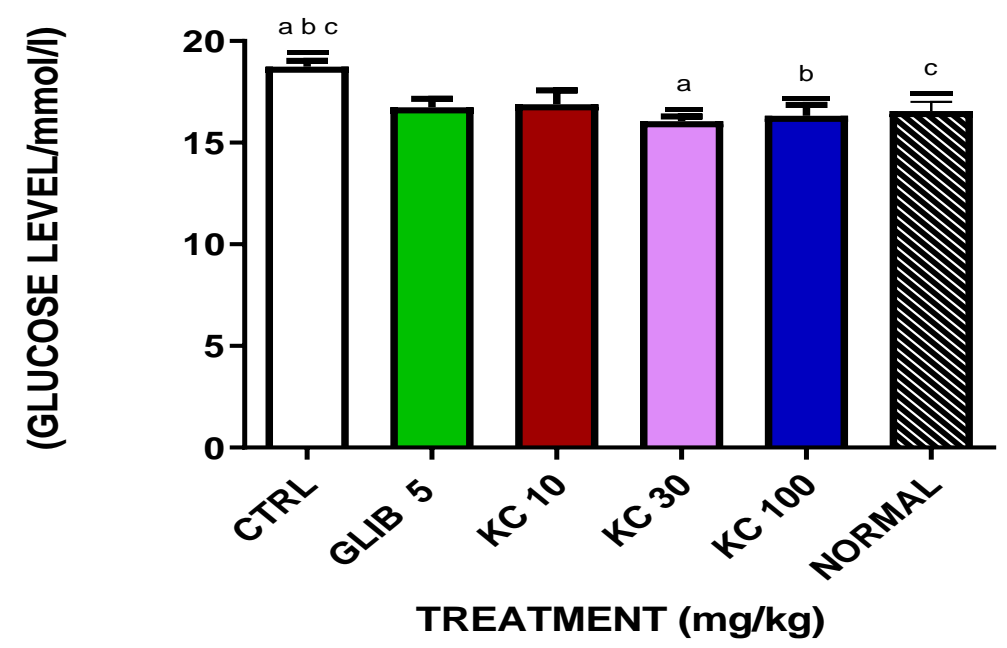

Fig. 3. Changes in glucose levels after third week of treatment Error bars denote SEM, $n=5$

\subsection{Lipid Levels}

\subsubsection{Changes in lipid levels after treatments}

It was observed that there was a significant decrease in the total cholesterol, LDL-C, triglycerides and significant increase in HDL-C in the $5 \mathrm{mg} / \mathrm{kg}$ Glibenclamide treated rats compared with the control. In the $10 \mathrm{mg} / \mathrm{kg} \mathrm{KC}$ treated rats there was non-significant increase in total cholesterol and HDL-C but a significant decrease in triglycerides and LDL-C compared with the diabetic control. There was significant decrease in total cholesterol LDL-C and triglycerides but significant increase in HDL-C in the $30 \mathrm{mg} / \mathrm{kg} \mathrm{KC}$ treated rats compared with the control.

Comparing the $100 \mathrm{mg} / \mathrm{kg} \mathrm{KC}$ treated rats there was a significant decrease in LDL-C, total cholesterol, triglycerides and significant increase in HDL-C compared with the normal control (Fig. 4). 


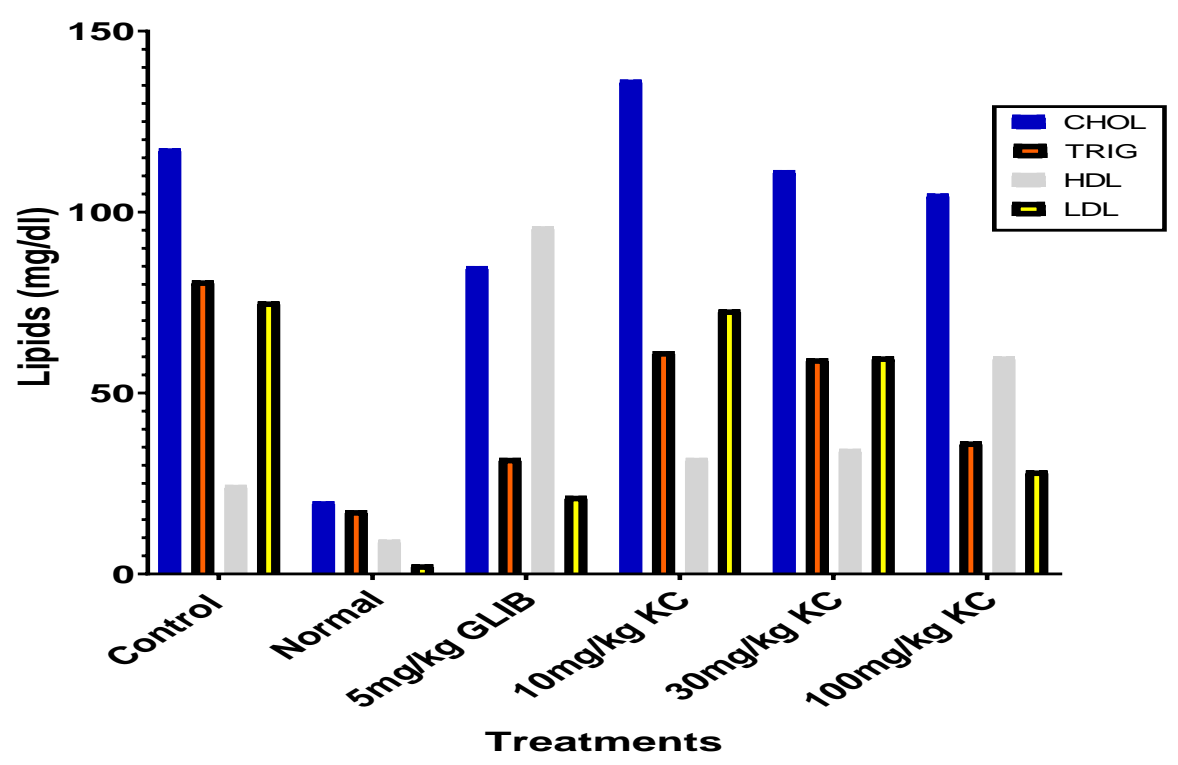

Fig. 4. changes in lipid levels in $\mathrm{mg} / \mathrm{dl}$ after the third week of treatment Error bars denote SEM, $n=5$

\subsection{Creatinine and Blood Urea Nitrogen Levels}

Creatinine levels decreased within each treatment group compared with the normal control (Fig/ 5A). There was a significant change in plasma creatinine levels between the $5 \mathrm{mg} / \mathrm{kg}$ Glibenclamide, $10 \mathrm{mg} / \mathrm{kg} \mathrm{KC}, 30 \mathrm{mg} / \mathrm{kg} \mathrm{KC}$ and $100 \mathrm{mg} / \mathrm{kg} \mathrm{KC}$ compared with the normal control $(p<0.0001)$. From Fig. 5B the blood urea nitrogen decreased within each treatment group compared with the normal control. There was a significant change in the blood urea nitrogen levels within the $5 \mathrm{mg} / \mathrm{kg}$ Glib, 30 and the $100 \mathrm{mg} / \mathrm{kg} \mathrm{KC}$ treatment groups $(p<0.0001)$. There was a non-significant change in the blood urea nitrogen in the $10 \mathrm{mg} / \mathrm{kg} \mathrm{KC}$ compared with the control group $(p>0.0001)$.

\section{$A$; changes in creatinine after treatments and $B$; changes in blood urea nitrogen after}

$\boldsymbol{A}$

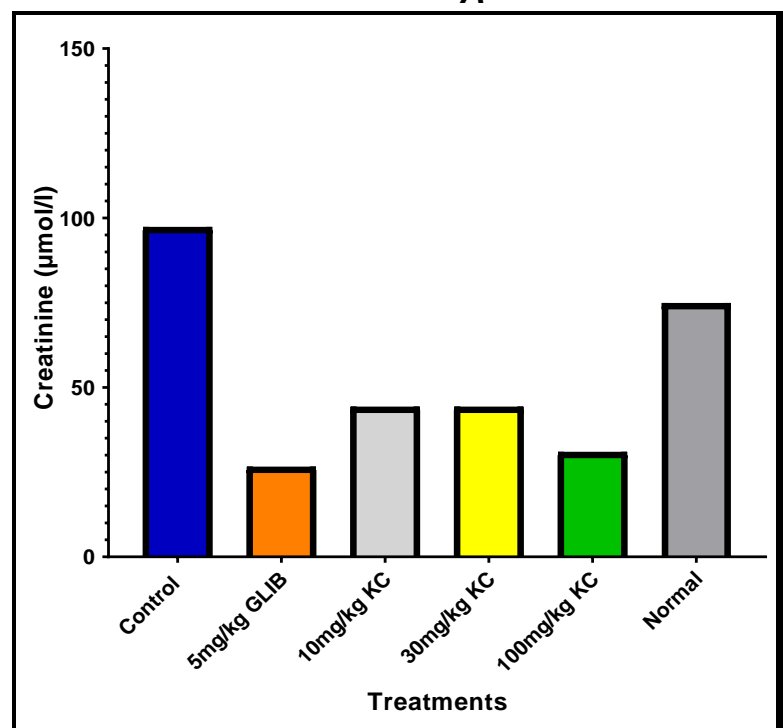

$B$

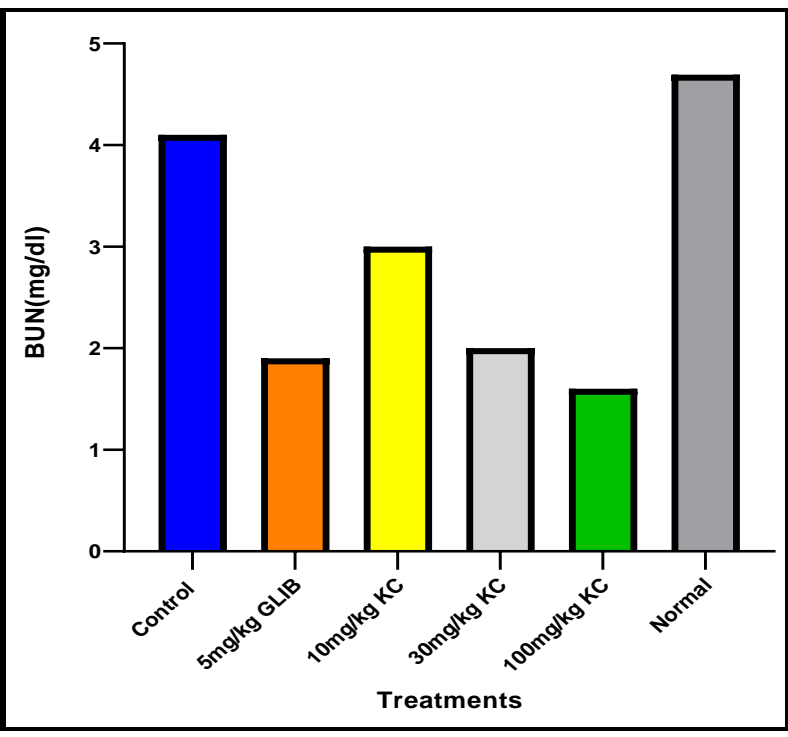

Fig. 5. A; changes in creatinine levels after third week of treatment, B; changes in blood urea nitrogen after third week of treatment 


\subsection{Liver Enzymes and Bilirubin Levels}

ALP levels decreased significantly in all the treatment groups $(5 \mathrm{mg} / \mathrm{kg}$ glib, $10 \mathrm{mg} / \mathrm{kg}$, $30 \mathrm{mg} / \mathrm{kg}$ and $100 \mathrm{mg} / \mathrm{kg} \mathrm{KC}$ treated rats) compared with the control. $(p<0.005)$.GGT levels decreased significantly in all the test groups ( $5 \mathrm{mg} / \mathrm{kg} \mathrm{glib,} 10 \mathrm{mg} / \mathrm{kg} \mathrm{KC}, 30 \mathrm{mg} / \mathrm{kg} \mathrm{KC}$ and $100 \mathrm{mg} / \mathrm{kg} \mathrm{KC}$ ) compared with the control group. $(p<0.005)$. Alanine transaminase (ALT) and Aspartate amino transferase (AST) both decreased significantly in $5 \mathrm{mg} / \mathrm{kg}$ Glibenclamide, $10 \mathrm{mg} / \mathrm{kg} \mathrm{KC}, 30 \mathrm{mg} / \mathrm{kg} \mathrm{KC}$ and $100 \mathrm{mg} / \mathrm{kg} \mathrm{KC}$ compared with the diabetic control. $(p<0.05)$. Total bilirubin (BIT) decreased significantly in all the treatment groups $(5 \mathrm{mg} / \mathrm{kg}$ glib, 10,30 and $100 \mathrm{mg} / \mathrm{kg} \mathrm{KC}) .(p<0.005)$.
A

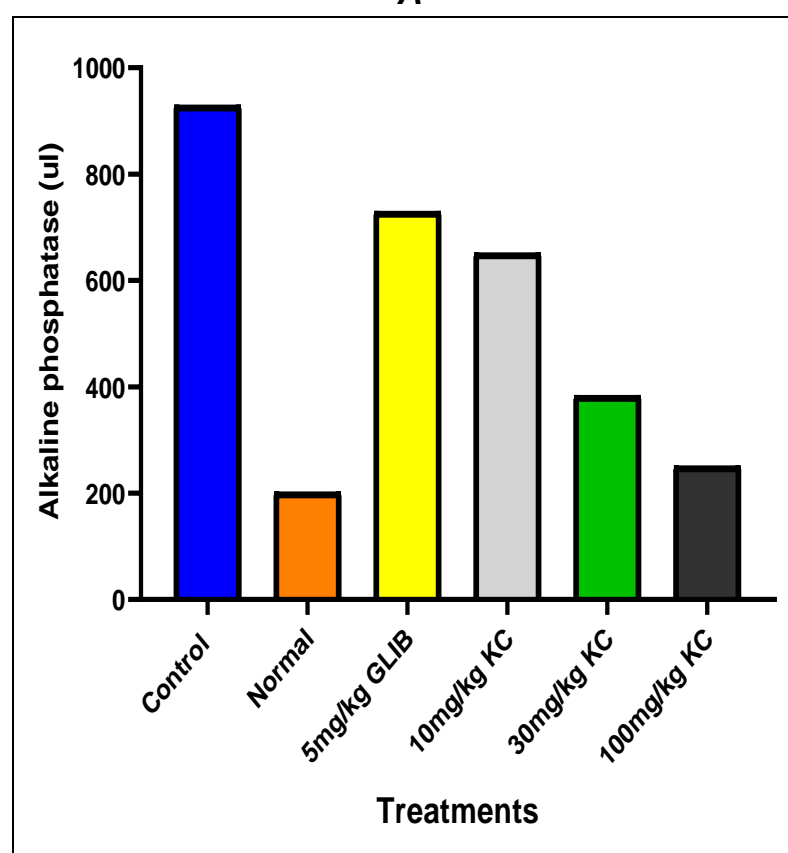

B

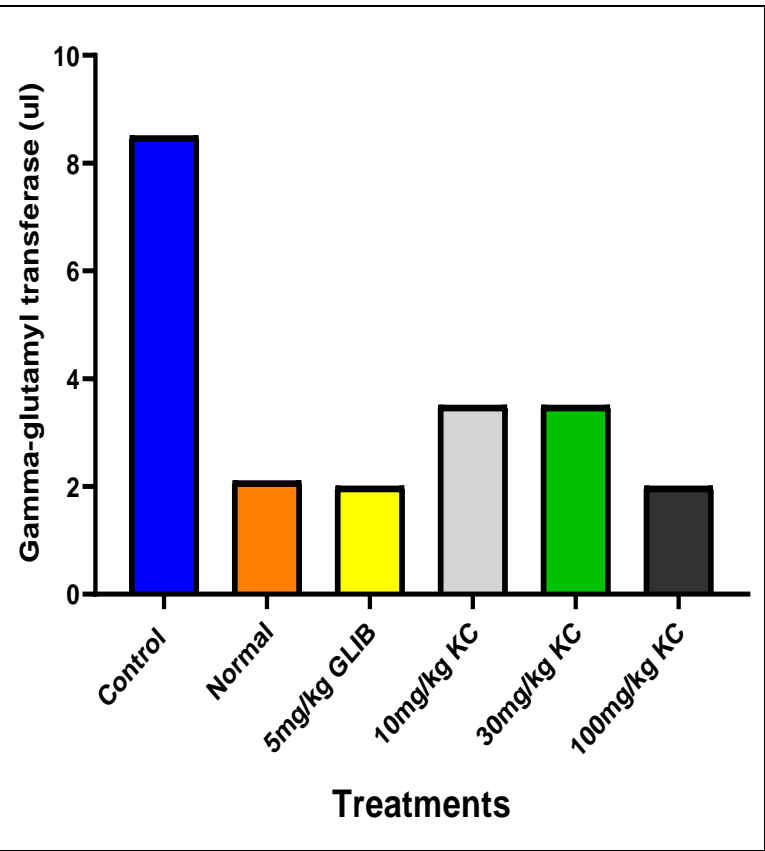

C

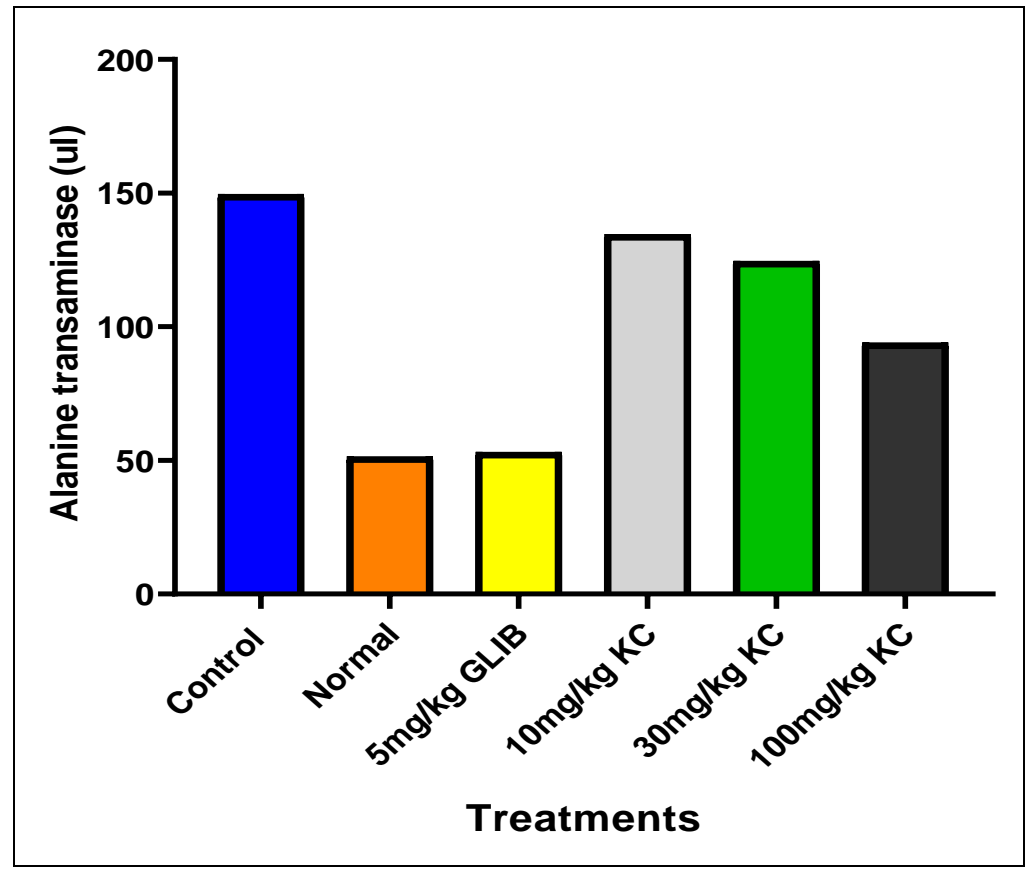


$\boldsymbol{D}$

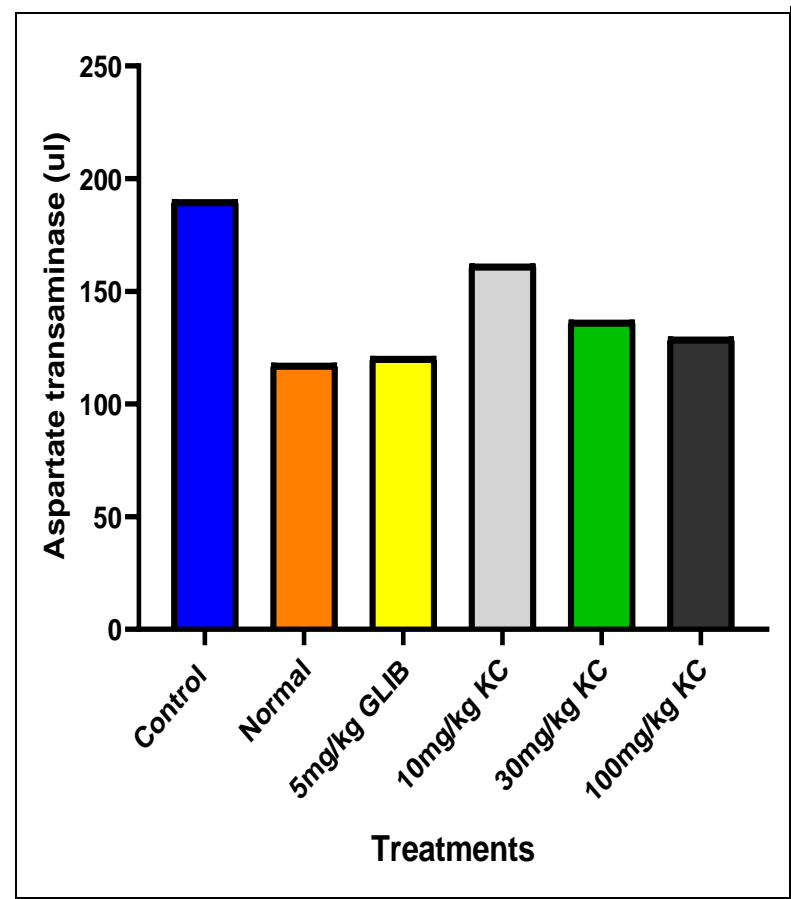

$E$

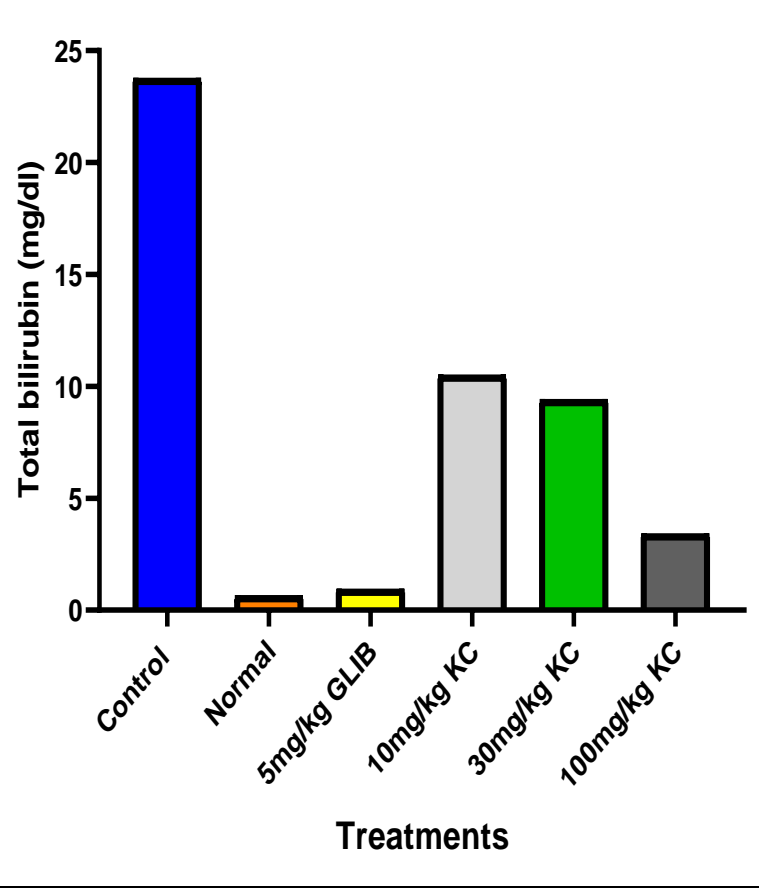

Fig. 6. A; Changes in Alkaline phosphatase (ALP), B; Gamma-glutamyl transferase (GGT), C; Aspartate transaminase (AST), D; Alanine transaminase (ALT) and E; Total bilirubin (BIT) levels

Changes in Alkaline phosphatase (ALP), Gamma-glutamyl transferase (GGT), Aspartate transaminase (AST) and Alanine transaminase $(A L T)$ in $u / l$ and Total bilirubin $(B I T)$ in $\mathrm{mg} / \mathrm{dl}$ after third week of treatment

\subsection{Histopathology}
A: Normal rats
B: Diabetic untreated rat
C: $100 \mathrm{mg} / \mathrm{kg}$ extract treated rat
D: $30 \mathrm{mg} / \mathrm{kg}$ extract treated rat
E: $10 \mathrm{mg} / \mathrm{kg}$ extract treated rat
F: Glibenclamide treated rat

\subsubsection{Histological analysis}

Examined liver sections from the normal rats revealed normal histological structure of hepatocytes; hepatocytes were polygonal in shape, tightly parked, containing basophilic central rounded nuclei separated by the hepatic sinusoids which radiates from the central vein $(\mathrm{CV})$, and with the presence of non-activated spindle shaped Kupffer cells within the sinusoids (Fig. 6A). Liver sections from negative control diabetic rats showed activation of Kupffer cells, tissue section appears eodematous, showing marked dilatation of CV and hepatic sinusoids, with the presence of highly basophilic nuclei of some hepatocytes (Fig. 6B). In Fig. 6C, section appears normal, with 6D being slightly eodematous with few highly basophilic nuclei of hepatocytes. Fig. 6E also showed eodematous tissue sections with dilatation of CV and sinosoids, and the presence of few highly basophilic nuclei of hepatocytes and activated Kupffer cells. For $6 \mathrm{~F}$, sections appear normal with few activated Kupffer cells and with most of the hepatocytes being slightly basophilic than normal, with nuclei being more conspicuous than the ones in $6 \mathrm{~A}$ and $6 \mathrm{C}$.

Examined sections of the cortex of the kidney from the normal rats (Fig. 7A), revealed normal histological structure of tubules and renal corpuscles (with well-defined capsular space). Kidney sections from negative control diabetic rats (Fig. 7B), showed diminished outline of renal corpuscles, absence of capsular space and with loss of the glomerular in some corpuscles from the cortex, which predicts degeneration of cells in the kidney of this group. In Fig. 7C, the sections had atrophied renal tubules and corpuscles with intact capsular space, predictive of regeneration of kidney tubules. Fig. 7D, had diminished outline of renal corpuscles and absence of capsular space, with 7E having a semi-capsular space around the glomerulus of the corpuscles, and loss of glomerulus represented by an empty 
space in corpuscle and signs of atrophy of the corpuscles. Histological sections from this group (7F), showed normal histology of renal tubules and corpuscles with well-defined capsular space, which reveals regeneration of cells.

Liver
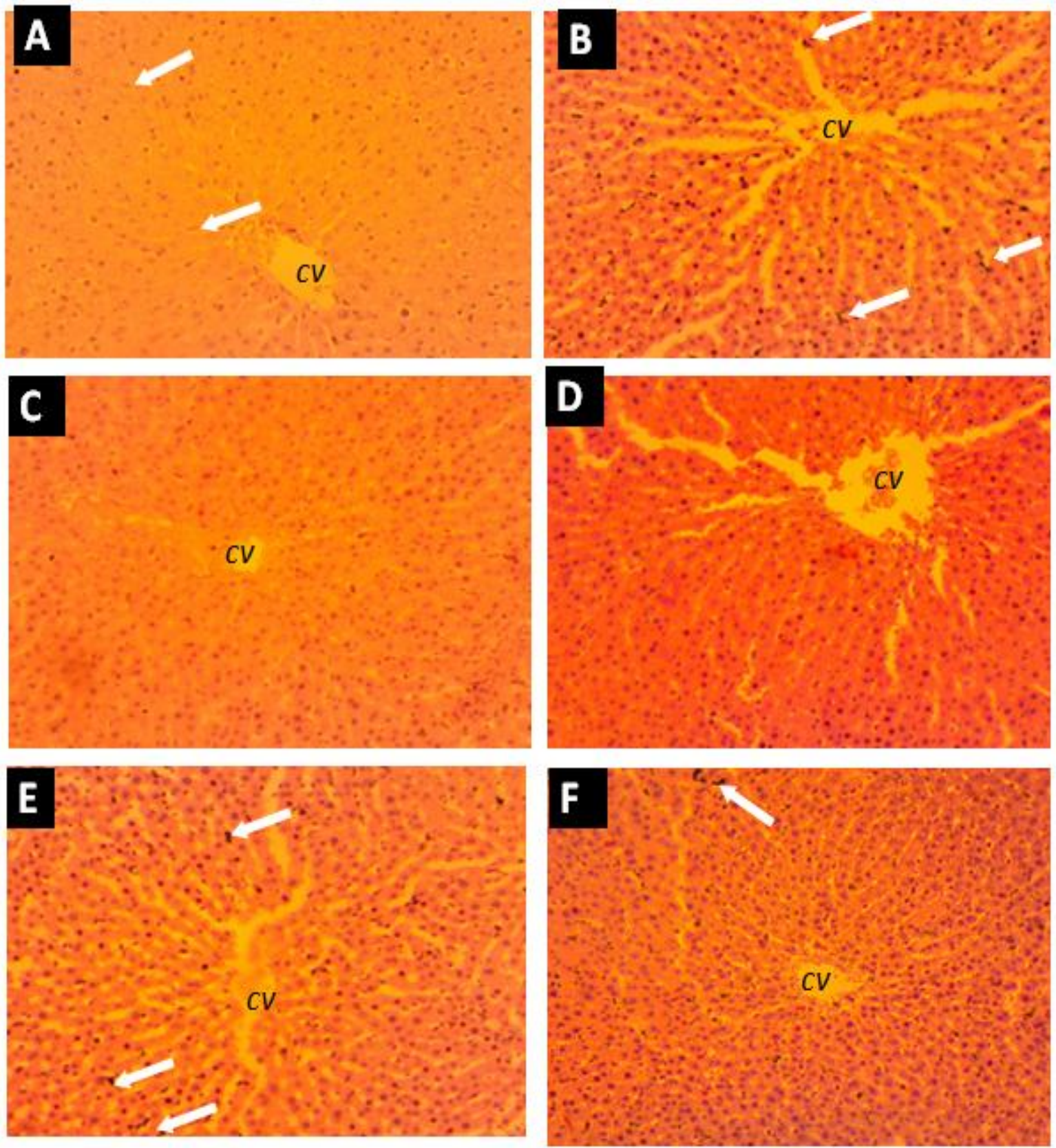

Fig. 7. Photomicrograph of liver sections of albino rats. (A) Normal histology with non-activate Kupffer cells (white arrows. (B) Tissue section appears eodematous, with the presence of activated Kupffer cells (white arrows) with some highly basophilic nuclei of some hepatocytes.

(C) Section appears normal. (D) Slightly eodematous with few highly basophilic nuclei of hepatocytes (E) Eodematous with few highly basophilic nuclei of hepatocytes and activated Kupffer cells (white arrow). (F) Section appears normal with few activated Kupffer cells (H\&E stain $100 X)$ 


\section{Kidney}
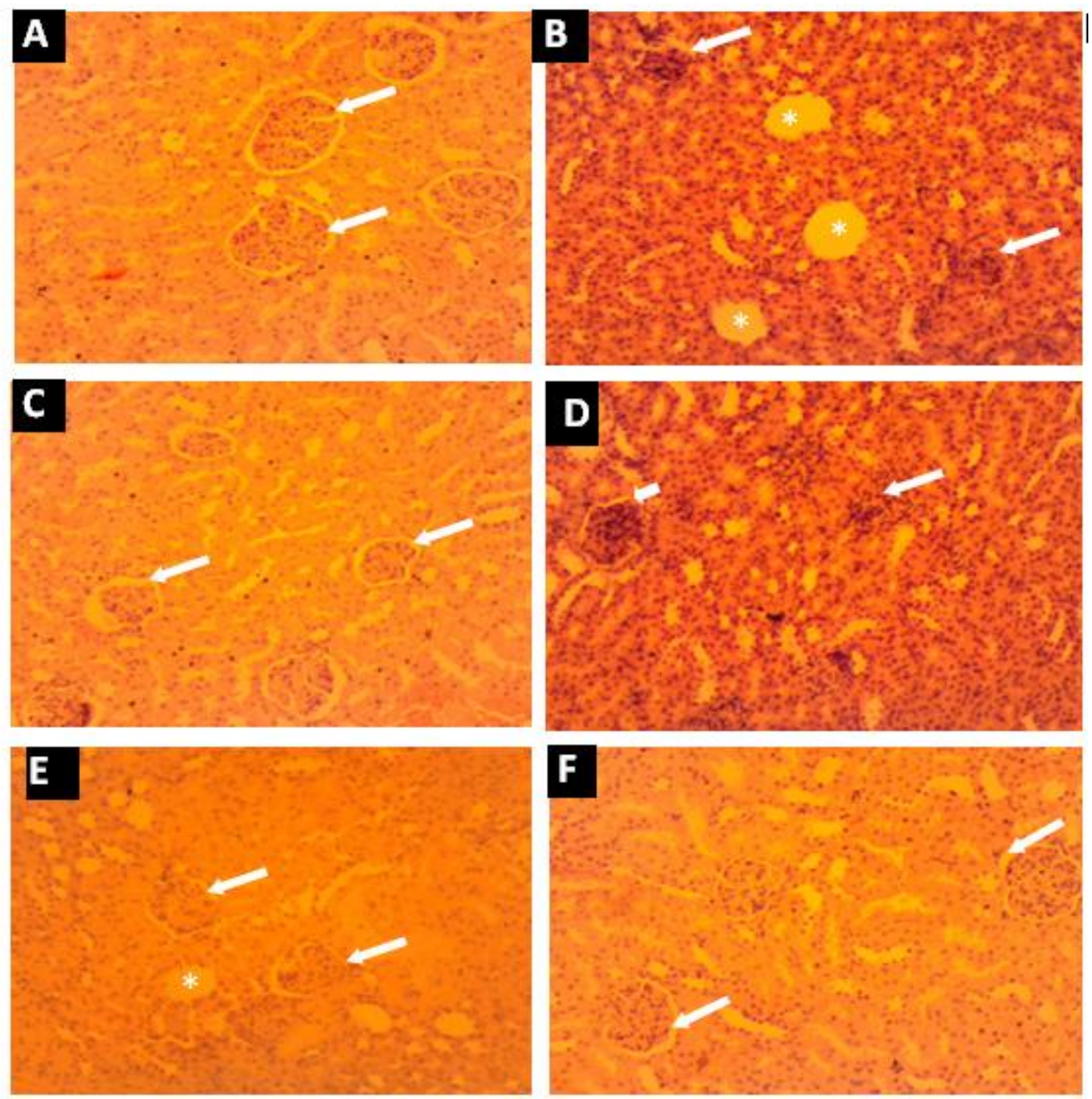

Fig. 8. Photomicrograph of kidney sections of albino rats. (A) Normal histology of tubules, renal corpuscles and a well-defined capsular space (white arrows). (B) diminished outline of renal corpuscles and absence of capsular space (white arrows), with loss of the glomerular in some corpuscles (asterisks). (C) Atrophy of tubules and corpuscles with intact capsular space (white arrow). (D) diminished outline of renal corpuscles (long white arrow) and absence of capsular space (short white arrow). (E) A semi-capsular space (white arrows) around the glomerulus of the corpuscles, and loss of glomerulus represented by an empty space (asteriks) in corpuscle and signs of atrophy of the corpuscles. (F) Normal histology of tubules, renal corpuscles and a well-defined capsular space (white arrows)

Examined section of the pancreas from the normal rats show normal histology of the endocrine islets of langerhans, exocrine acinar cells and pancreatic connective tissue septa (Fig. $8 \mathrm{~A}$ ). In the diabetic control experimental rats (Fig. $8 B$ ), damage of cells mostly from the mid part of the endocrine islets of Langerhans, thus displayed localized degeneration of cells at the centre, with highly basophilic nuclei of surrounding secretory exocrine acinar cells. Irregularly arranged peripherally placed islet cells. Also both islet of langerhans displaying degenerative and necrotic changes in diabetic control rats. Fig. $8 \mathrm{C}$ shows histological section 
which appears normal with normal Islet of langerhans associated with the ordinary control group. Decrease of cells within the center parcel of the islets of langerhans (Fig. 8D). Islet of Langerhans displaying decrease in size with degenerative cells with sign of little regeneration in the middle, with regularly arranged peripheral islet cells, with $8 \mathrm{E}$ showing regeneration of cells in the mid part of the islets of Langerhans, with intact and uniformly arranged peripheral islet cells. Fig. 8F shows total regeneration of cells at the centre of the islet of Langerhans.

\section{Pancreas}
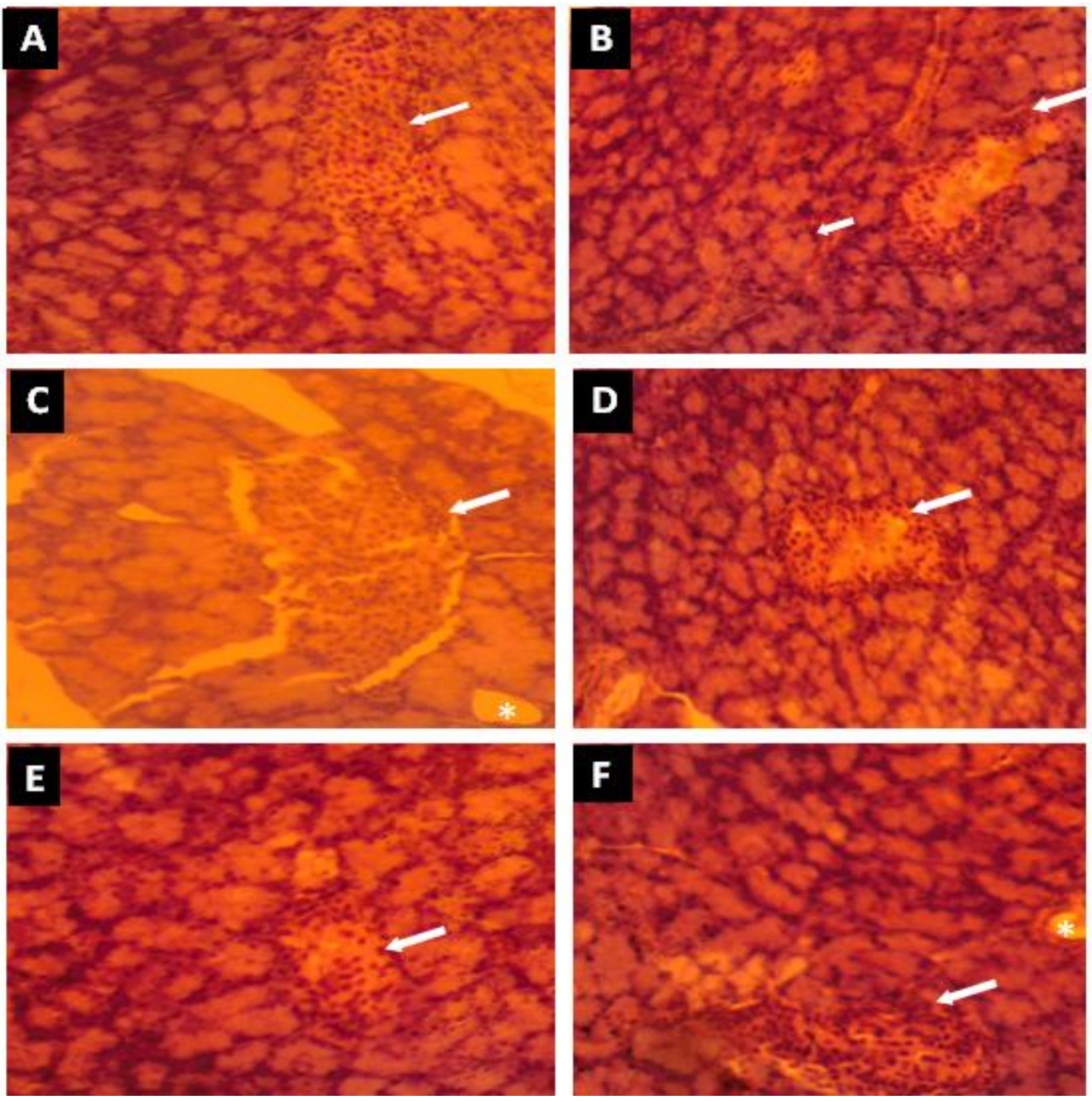

Fig. 9. Photomicrograph of histological sections of the pancreas of albino rats. (A) section of the pancreas with normal histology of the Islets of Langerhans (white arrows). (B) Loss of cells mostly from the middle portion of the endocrine Islets of Langerhans (long white arrows), with highly basophilic nuclei of surrounding secretory exocrine acinar cells (short white arrow). (C) histological section appears normal with normal Islet of Langerhans (white arrow) and the presence of an intralobular duct (asterisks) of the exocrine acinar. (D) Reduction of cells in the middle portion of the Islets of Langerhans (white arrows). Sign of little regeneration.(E) Regeneration of cells in the middle portion of the Islets of Langerhans (white arrows). (F) Total regeneration of Islet cells (white arrows). Presence of intralobular duct of the exocrine acinar (asterisks) (H\&E stain 100X) 


\section{DISCUSSION}

DM is a global health problem and which many developing countries are looking for new ways of managing this condition. Many have resorted to the use of herbal medicine. Thus, it has become necessary for scientist to research into the efficacy of plants with anti-diabetic properties for medicinal purposes.

The study assessed the effect of leaves and stem of $K$. crenata $(\mathrm{KC})$ ethanolic extract on renal and liver impairement, dyslipidemia and glycemia in streptozotocin induced diabetic rats. Phytochemical examination revealed the presence of Alkaloids, Glycosides, Phenolics, Flavonoids, Triterpenes, Anthraquinones, Steroids, Tannins, Terpenoids and Saponins which supports work done by [42], which showed the presence of all these compounds in a methanol extract of kalanchoe sp.

In the study, $5 \mathrm{mg} / \mathrm{kg}$ glibenclamide, $30 \mathrm{mg} / \mathrm{kg}$ and $100 \mathrm{mg} / \mathrm{kg}$ ethanolic extract of KC showed a significant reduction in blood glucose levels compared with the control group in the STZ induced diabetic rats. The $10 \mathrm{mg} / \mathrm{kg} \mathrm{KC}$ extract also showed a non-significant reduction in the blood glucose levels compared with the control group, which indicates that low concentration of extract has a minimal effect on the recovery of the pancreatic cells (islet cells of Langerhans) resulting in low levels of insulin production and hence the insignificant reduction of the blood glucose. The decrease in the blood glucose was as a result of the presence of terpenoids in the extract. Terpenoids are known to reduce blood glucose through many mechanisms which include insulin-like activity, inhibition of gluconeogenesis and glycogenolysis [43]. Terpenoids targets the hepatocytes to reduce the enzymatic activity of phosphorylase kinase and glycogen phosphorylase to reduce the breakdown of stored glycogen to glucose -1phospate in the hepatocytes. Terpenoids also target the liver and kidney and slows down carboxykinase activity. This results in the reduction of the convention of non-carbohydrate substrates such as lactate, amino acid and glycerol.

$\mathrm{KC}$ also contains flavonoids and tannins that are known to decrease blood glucose through reduction in the intestinal absorption of glucose [44]. Both tannins and flavonoids interfere with the activity of the sodium-glucose cotransporters in the epithelium of the small intestines reducing the level of glucose absorbed into the blood stream.

With lipidemia, rats treated with KC $(30,100$ $\mathrm{mg} / \mathrm{kg}$ ) and $5 \mathrm{mg} / \mathrm{kg}$ glibenclamide showed decreased total cholesterol, triglycerides and LDL-C and increased HDL-C. The $10 \mathrm{mg} / \mathrm{kg} \mathrm{KC}$ showed a no significant increase in total cholesterol and HDL-C but decrease in triglycerides and LDL-C. This suggest that 30 $\mathrm{mg} / \mathrm{kg}$ and $100 \mathrm{mg} / \mathrm{kg} \mathrm{KC}$ extract has a dyslipidemic effect due to the presence of flavonoids which play a role in decreasing LDL-C and total cholesterol and increasing HDL-C [45], and that $10 \mathrm{mg} / \mathrm{kg} \mathrm{KC}$ was not effective in controlling these parameters.

Renal function was assessed by measuring creatinine and blood urea nitrogen (BUN). Creatinine levels in the blood decreased in all the treatment groups $(5 \mathrm{mg} / \mathrm{kg}$ glibenclamide, 10 , $30,100 \mathrm{mg} / \mathrm{kg} \mathrm{KC}$ ) after week 3 compared with the control which suggests the effectiveness of these treatments in recovering kidney tissue damage after the third week of induction of DM and also suggests a non-toxic effect of the extract on the kidney. This supports work done by [45], which showed a significant decrease in blood creatinine levels after administration of flavonoids to induced diabetic rats since flavonoid was also screened in the KC extract in this study.

Blood urea nitrogen (BUN) also decreased in all the treatment groups $(5 \mathrm{mg} / \mathrm{kg}$ glibenclamide, 10 , 30 and $100 \mathrm{mg} / \mathrm{kg} \mathrm{KC}$ ), which suggests that 10 , 30 and $100 \mathrm{mg} / \mathrm{kg} \mathrm{KC}$ treatment groups reduced kidney tissue damage due to the presence of tannins and flavonoids in the KC extract [46].

Liver function test (LFT) was assessed by measuring Aspartate transaminase (AST), Alanine transaminase (ALT), Alkaline phosphatase (ALP), Gamma-glutamyl transferase (GGT) and Total bilirubin (BIT) after week 3 of treatment.

After the third week of treatment AST, ALT, ALP, GGT and BIT all decreased significantly in all the treatment groups $(5 \mathrm{mg} / \mathrm{kg}$ glibenclamide, 10,30 and $100 \mathrm{mg} / \mathrm{kg} \mathrm{KC}$ ) compared with the control group which suggests improved liver functioning. It further explains the fact that damaged liver tissues of the control group were improved in the treatment groups from week 1 to week 3 explaining the effective treatment actions on liver repair by all the test groups which confirms work 
done by [47]. Decrease in AST and ALT suggest no hepatocellular damage to the liver tissues, whereas decrease in GGT and ALP suggest no cholestasis.

From the results negative untreated diabetic rats showed marked histological changes of liver sections. It was also observed that an increase in dose of extract $(30-100 \mathrm{mg} / \mathrm{kg})$ of extract showed different degrees of hepatoprotective and regenerative effects on the hepatocytes of the rats, with high dose $(100 \mathrm{mg} / \mathrm{kg})$ showing the highest signs of regenerative potential of the extract .This findings agrees with work done by $[14,48]$.

The histopathological changes observed in the pancreas revealed islet degeneration of the negative control groups, whiles in the extract treated diabetic rats, the higher dose $(100 \mathrm{mg} / \mathrm{kg})$ showed the highest degree of regeneration with cyto -architecture resembling that of the normal rats. The other doses (10 and $30 \mathrm{mg} / \mathrm{kg}$ extract), however showed moderate signs of regeneration (Fig. 8). Thus, the higher the dose, the greater the degree of regeneration of the beta cells of the islet. This finding agrees with other research works carried elsewhere ${ }^{24}$ using different plant extract.

Histology of kidney sections of negative control rats showed tubular degeneration, necrosis, and distortion of cyto-architecture of renal corpuscles which seems to be reversed in the extract treated diabetic rats. This finding agrees with a work done by [49].

\section{CONCLUSION}

The outcome of the experiment showed that the ethanol extract of $K$. Crenata, at 30 and 100 $\mathrm{mg} / \mathrm{kg}$ body weight doses, lowered blood glucose and improved lipidemia by decreasing total cholesterol and LDL-C and increasing HDL-C. These dosages showed decrease in ALP, GGT, $A L T$, and AST and also showed reduction in total bilirubin. Therefore, the extract contains antidiabetic and some anti-nephropathic properties which may explain the herbal use of this plant for the treatment and management of DM and its other health complications such as nephropathy and antheroslerosis. Hence, the active components of the extract hold promise for the production of a potent and standard herbal medicine for the management of DM, kidney and liver diseases and also has no or little toxic effect on the liver, pancreas and the kidney.

\section{CONSENT}

It is not applicable.

\section{ETHICAL APPROVAL}

The research was approved by the Institutional Review Board, University of Cape Coast, Ghana (ethical clearance number UCC IRB/CHAS/2016).

\section{COMPETING INTERESTS}

Authors have declared that no competing interests exist.

\section{REFERENCES}

1. Gale J. India's diabetes epidemic cuts down millions who escape poverty. Bloomberg. Retrieved. 2012;8.

2. Giri B, et al. Chronic hyperglycemia mediated physiological alteration and metabolic distortion leads to organ dysfunction, infection, cancer progression and other pathophysiological consequences: An update on glucose toxicity. Biomedicine \& Pharmacotherapy. 2018;107:306-328.

3. Koye DN, et al., The global epidemiology of diabetes and kidney disease. Advances in Chronic Kidney Disease. 2018;25(2):121-132.

4. Nouh F, Omar M, Younis M. Gestational Diabetes Mellitus; Mother and Infancy Outcome. Pancreas. 2017;20:28-29.

5. Sarkar BK, et al., Diabetes mellitus: A comprehensive review. Journal of Pharmacognosy and Phytochemistry. 2019;8(6):2362-2371.

6. Zhou B, et al. Worldwide trends in diabetes since 1980: A pooled analysis of 751 population-based studies with 4. 4 million participants. The Lancet. 2016;387(10027): 1513-1530.

7. Zheng Y, SH Ley, Hu FB. Global aetiology and epidemiology of type 2 diabetes mellitus and its complications. Nature Reviews Endocrinology. 2018;14(2):88.

8. Amoah AG, Owusu SK, Adjei S. Diabetes in Ghana: A community based prevalence study in Greater Accra. Diabetes Research and Clinical Practice. 2002;56(3): 197-205.

9. Thomas MC, Cooper ME, Zimmet P. Changing epidemiology of type 2 diabetes mellitus and associated chronic kidney 
disease. Nature Reviews Nephrology. 2016;12(2):73.

10. Bawah AT, et al., A community based prevalence of type 2 diabetes mellitus in the Ho municipality of Ghana. Journal of Public Health. 2019;1-7.

11. Hernandez AF, et al. Albiglutide and cardiovascular outcomes in patients with type 2 diabetes and cardiovascular disease (Harmony Outcomes): A doubleblind, randomised placebo-controlled trial. The Lancet. 2018;392(10157):1519-1529.

12. Katsiki N, Mikhailidis DP, Banach M. Leptin, cardiovascular diseases and type 2 diabetes mellitus. Acta Pharmacologica Sinica. 2018;39(7):1176-1188.

13. Tavares CAF, et al., Screening for asymptomatic coronary artery disease in patients with type 2 diabetes mellitus. Archives of Endocrinology and Metabolism. 2016;60(2):143-151.

14. Khattab HA, Al-Amoudi NS, Al-Faleh A. Effect of ginger, curcumin and their mixture on blood glucose and lipids in diabetic rats. Life Science Journal. 2013; 10(4):428-442.

15. Schiffer TA, Friederich-Persson $M$. Mitochondrial reactive oxygen species and kidney hypoxia in the development of diabetic nephropathy. Frontiers in Physiology. 2017;8:211.

16. Yaribeygi $\mathrm{H}$, et al. Oxidative stress induces renal failure: A review of possible molecular pathways. Journal of Cellular Biochemistry. 2018;119(4):2990-2998.

17. Chaudhury A, et al. Clinical review of antidiabetic drugs: implications for type 2 diabetes mellitus management. Frontiers in Endocrinology. 2017;8:6.

18. Adinortey MB, et al. Phytomedicines used for diabetes mellitus in Ghana: A systematic search and review of preclinical and clinical evidence. Evidence-Based Complementary and Alternative Medicine; 2019.

19. Mohammed A, Koorbanally NA, Islam MS. Anti-diabetic effect of Xylopia aethiopica (Dunal) A. Rich.(Annonaceae) fruit acetone fraction in a type 2 diabetes model of rats. Journal of Ethnopharmacology. 2016;180: 131-139.

20. Iddrisu I, Chikwere P. Plants and mushrooms in the management of diabetes. World Nutrition, 2020;11(1):190209.

21. Comalada $\mathrm{M}$, et al. In vivo quercitrin antiinflammatory effect involves release of quercetin, which inhibits inflammation through down-regulation of the NF-KB pathway. European Journal of Immunology. 2005;35(2):584-592.

22. Yalcin H, Capar TD. Bioactive compounds of fruits and vegetables, in Minimally Processed Refrigerated Fruits and Vegetables. Springer. 2017;723-745.

23. Zaidun $\mathrm{NH}$, Thent ZC, Abd Latiff A. Combating oxidative stress disorders with citrus flavonoid: Naringenin. Life Sciences. 2018;208:111-122.

24. Uhegbu FO, et al. Renal Protective Properties of Aqueous Extract of Bryophyllum pinnatum (Lam.) Oken Leaf against Petrol Vapour-Induced Toxicity on Male Albino Rats. European Journal of Medicinal Plants. 2017;1-8.

25. Odugbemi TO, et al., Medicinal plants useful for malaria therapy in Okeigbo, Ondo State, Southwest Nigeria. African Journal of Traditional, Complementary and Alternative Medicines. 2007;4(2):191-198.

26. Adetutu A, Morgan WA, Corcoran O. Ethnopharmacological survey and in vitro evaluation of wound-healing plants used in South-western Nigeria. Journal of Ethnopharmacology. 2011;137(1):50-56.

27. Iwu MM. Pharmacognostical profile of selected medicinal plants; 2014.

28. Uzoigwe C, Agwa O. Antimicrobial activity of Vernonia amygdalina on selected urinary tract pathogens. African Journal of Microbiology Research. 2011;5(12):14671472.

29. Alo M, et al. Antibacterial activity of water, ethanol and methanol extracts of Ocimum gratissimum, Vernonia amygdalina and Aframomum melegueta. Adv. Appl. Sci. Res. 2012;3(2):844-848.

30. Pesewu GA, Cutler RR, Humber DP. Antibacterial activity of plants used in traditional medicines of Ghana with particular reference to MRSA. Journal of Ethnopharmacology. 2008;116(1):102-111.

31. Addai-Mensah $\mathrm{O}$, et al. Regular antenatal attendance and education influence the uptake of intermittent preventive treatment of malaria in pregnancy: A cross-sectional study at the university hospital, Kumasi, Ghana. Journal of Tropical Medicine; 2018.

32. Crenata KIV. Vascular effects of an aqueous extract of kalanchoe integra Var. Crenata (Andr.) Cuf Leaves: Reversal of Postischaemic Dysautoregulation in a Rat Model of Cerebral Ischaemia; 2013. 
33. De S, Dey YN, Ghosh AK. Phytochemical investigation and chromatographic evaluation of the different extracts of tuber of Amorphaphallus paeoniifolius (Araceae). Int J Pharm Biol Res. 2010;1(5):150-7.

34. Kokate CK. Practical Pharmacognosy. 4 [sup] th ed. New Delhi: Vallabh Prakashan. 1994;107.

35. Harborne JB. Phenolic compounds, in Phytochemical methods. Springer. 1973;33-88.

36. Marinova D, Ribarova F, Atanassova M. Total phenolics and total flavonoids in Bulgarian fruits and vegetables. Journal of the University of Chemical Technology and Metallurgy. 2005;40(3):255-260.

37. Smith J, et al. Principles and practice in ethical review of animal experiments across Europe: summary of the report of a FELASA working group on ethical evaluation of animal experiments. Laboratory Animals. 2007;41(2):143-160.

38. Rao GMM, et al. Hepatoprotective effects of rubiadin, a major constituent of Rubia cordifolia Linn. Journal of Ethnopharmacology. 2006;103(3):484-490.

39. Mezban NA, Hussein AM. Comparative study to some of the biochemical and histological effects of alkaloids extracts from Nerium oleander and Apium graveolens in females mice Mus musculus l; 2015.

40. Walker N, Gupta R, Cheesbrough J. Blood pressure cuffs: friend or foe? Journal of Hospital Infection. 2006;63(2):167169.

41. Šapčanin A, et al. Calculation of Hazard Quotient Based on the Content of Heavy Metals in Different Mushrooms. Springer.
42. Ayoola G, et al. Phytochemical screening and antioxidant activities of some selected medicinal plants used for malaria therapy in Southwestern Nigeria. Tropical Journal of Pharmaceutical Research. 2008;7(3):1019-1024.

43. Grover J, Yadav S, Vats V. Medicinal plants of India with anti-diabetic potential. Journal of Ethnopharmacology. 2002;81(1):81-100.

44. Montilla MP, et al. Antioxidant activity of maslinic acid, a triterpene derivative obtained from Olea europaea. Planta Medica. 2003;69(05):472-474.

45. Wang $\mathrm{Y}$, et al. Progressive adriamycin nephropathy in mice: Sequence of histologic and immunohistochemical events. Kidney International. 2000;58(4):1797-1804.

46. Marwat SK, et al. Useful ethnophytomedicinal recipes of angiosperms used against diabetes in South East Asian Countries (India, Pakistan \& Sri Lanka). Pakistan Journal of Pharmaceutical Sciences. 2014;27(5).

47. Nyblom $\mathrm{H}$, et al. High AST/ALT ratio may indicate advanced alcoholic liver disease rather than heavy drinking. Alcohol and Alcoholism, 2004;39(4):336-339.

48. Murugan P, Pari L. Antioxidant effect of tetrahydrocurcumin in streptozotocinnicotinamide induced diabetic rats. Life Sciences. 2006;79(18):1720-1728.

49. Gwim EC, Eand Oloyede OB. Ethanolic extract of cashew leaves restores hepatic and renal integrity in streptozotocininduced diabetic rats. Journal of Pharmaceutical and Biomedical Sciences. $2011 ; 6(01)$.

(0) 2021 Effah-Yeboah et al.; This is an Open Access article distributed under the terms of the Creative Commons Attribution License (http://creativecommons.org/licenses/by/4.0), which permits unrestricted use, distribution, and reproduction in any medium, provided the original work is properly cited.

The peer review history for this paper can be accessed here: https://www.sdiarticle5.com/review-history/75641 